\title{
Physicochemistry of hexadecylammonium bromide and its methyl and ethanolic head group analogues in buffered aqueous and gelatin solution
}

\author{
DEBOLINA MITRA and SATYA P MOULIK* \\ Centre for Surface Science, Department of Chemistry, Jadavpur University, Kolkata 700032 \\ e-mail: spmcss@yahoo.com
}

MS received 30 August 2009; accepted 26 November 2009

\begin{abstract}
In this work, the interfacial and bulk behaviour of the amphiphiles hexadecylammonium bromide and its methyl and ethanolic head group analogues in buffered aqueous and gelatin solution has been examined. The analogues are of two categories: the methyl and the combined methyl and ethanolic head group representatives are considered as Group A compounds, and all non-methyl but ethanolic head group species are taken as Group B compounds. Different physical techniques have been employed to ascertain the amphiphilic behaviour in solution. The self-aggregation of these surfactants at different $\mathrm{pH}$ has been studied along with $\mathrm{pH}$ dependent interfacial activity of gelatin. The interaction of the two categories of the surfactants with gelatin at different $\mathrm{pH}$ has been investigated. A scheme for this interaction at various stages of the process has been proposed. The influence of the surfactant head groups on the interaction process has been assessed.
\end{abstract}

Keywords. Gelatin; surfactant; interaction; pH; head group.

\section{Introduction}

The changes in the molecular architecture of amphiphiles have an important consequences on their physicochemical properties and diverse applications of their organized assemblies. ${ }^{1}$ Increased surfactant alkyl chain length results in a decreased critical micelle concentration $(\mathrm{cmc})$ and the degree of counterion dissociation, and increase both in the aggregation number and the Kraft point. ${ }^{1,2}$ Also by altering the counterion, effective micellar surface charge density changes with a concomitant alteration of micellar effect on reaction rates and equilibri. ${ }^{3}$ It also plays a controlling role in determining the exothermicity of micelle formation and structural changes in micelles by way of the altered microenvironment in the Stern layer. ${ }^{4}$ Modification of surfactant head group on micellar properties is a less explored field. In aqueous solution, on increasing the hydrophobic character of the head group, the rates of reactions sensitive to change in solvent polarity or steric factors are enhanced. ${ }^{5}$ Enzyme kinetics in microemulsion medium has also a direct

*For correspondence impact on head group variation. Surface active enzymes preferably reside at the oil-water interface in close proximity with substrates if the surfactant head group is large ${ }^{6-8}$ Thus, large hydrophobic headgroups partially exclude water from the interface resulting in a less polar reaction environment and leave ample spaces to accommodate substrate and enzymes.

The role of both polymer and surfactant in their interaction has been experimentally suggested by Goddard, ${ }^{9}$ Hayakawa and Kwak, ${ }^{10}$ and theoretically advanced by Nagarajan (who has proposed several types of possible arrangements of the interacted products) ${ }^{11}$ The NMR, ${ }^{12}$ SANS ${ }^{13}$ and fluorescence techniques $^{14}$ have significantly contributed to the revelation of possible structural features of the polymer-surfactant interacting systems. Cationic lipid-protein interaction has been the subject of detailed investigations over the past few decades because of their interest in fundamental science and biotechnological applications. ${ }^{15}$ In such cases, modification of either protein or surfactant architecture generates ample scope for designing the process as per need. It has been found that on altering the head group architecture of cationic lipid molecules, 
in vitro transfection efficiency of DNA drastically varies. In presence of hydrophilic moieties like hydroxyethyl group, glucose or polyethylene groups, the efficiency enhances considerably. ${ }^{16}$ Dasgupta et $a l^{7}$ and Chatterjee et $a l^{18}$ have studied the interactional and packing behaviour of DNA with a variety of hydroxylated cationic surfactants.

Gelatin is a protein extracted from collagen that occurs in animal's connective tissues, and widely used as a gelling agent in food, pharmaceutical, photography and cosmetic manufacturing, etc. ${ }^{19,20}$ The tendency of gelatin to form coacervates with other proteins or hydrocolloids makes it useful for precipitating materials that cause haze in wines, juice, vinegar, etc. The coacervate hardens in presence of an aldehyde and is used suitably for encapsulation in pharmaceutics. Gelatin also forms coacervates with oppositely charged surfactants, and to this end, studies have been mainly made with anionic surfactants. ${ }^{21-40}$ Interaction of gelatin with polyanions like sodium polystyrenesulfonate (NaPSS) or sodium poly(2-acrylamido-2-methylpropanesulfonate $)^{41}$ or mixed micelles of SDS and a sugar-based non-ionic surfactant ${ }^{42}$ have been found to depend on the critical mole fraction, charge density, and chain length of the surfactants. But reports on the interaction of gelatin with non-ionic surfactants ${ }^{43}$ or with cationic surfactants of varied types have been strikingly limited. $^{44-48}$

We have studied here the interaction of gelatin with the alkyltrimethylammonium bromide surfactants, and in particular the analogues of the $\mathrm{C}_{16}$ variety having modified head groups in detail. The surface and bulk properties have been examined by various techniques and a schematic illustration of the involved interaction processes has been proposed. Physicochemical and interactional properties of this kind have been scarcely explored in the past. ${ }^{17,18}$ The study has been performed at pHs 5.4 and 9.0 without and with gelatin. With reference to the reported gelatin-CTAB interaction profile, ${ }^{49}$ we have illustrated in detail and discussed the effects of the surfactant head group modification and $\mathrm{pH}$ on the said interaction process.

\section{Experimental}

\subsection{Materials}

Gelatin (average molar mass $38,000 \mathrm{~g} \mathrm{~mol}^{-1}$ and isoelectric $\mathrm{pH}$ (IEP) 4.84) was a product of Sigma
USA ( $>99 \%$ pure)); the sample we used earlier. ${ }^{44,45,49,50}$ Of the surfactants used, CTAB was an AR grade product of Aldrich (USA, $>99 \%$ ). The preparation and characterization of the other surfactants used were reported elsewhere. ${ }^{7,8,18,49,51}$ They are subdivided in two groups as presented in scheme 1. Borax and boric acid were AR grade products of Merck (India). Pyrene (Aldrich, USA) was a gift sample from the Polymer Science Laboratory of IACS, Kolkata, India. It was purified by vacuum sublimation and then crystallized twice from a $3: 1$ ethanol-water mixture. The water used in the study was doubly distilled water of specific conductance $2-4 \mu \mathrm{S} \mathrm{cm}^{-1}$ at $303 \mathrm{~K}$. The surfactants produced expected cmcs as reported in literature. ${ }^{49,51}$ They did not contain surface active impurities as $\gamma$ (surface tension) vs. $\log [$ surfactant $]$ plots did not produce minima.

\subsection{Methods}

Measurements were taken either in boric acid-borax buffer medium at $\mathrm{pH} 9$ or in acetic acid-sodium acetate buffer at $\mathrm{pH} 5.4$ and ionic strength, $\mu=0.005$. The biopolymer solution was prepared by dissolving a desired amount of dried gelatin flakes at room temperature to the aqueous buffer solution and allowing the biopolymer to swell for $30 \mathrm{~min}$. It was then heated to $313 \mathrm{~K}$ with constant stirring until complete dissolution. The solution was then thoroughly mixed by stirring, cooled to room temperature and stored for use. The concentration of gelatin used has been expressed in $\mathrm{g} \%(\mathrm{w} / \mathrm{v})$. The maximum [gelatin] used in this study was $0.05 \%$. The temperature for all experiments was $303 \mathrm{~K}$, which is far above the gelation temperature of gelatin. ${ }^{49}$

\section{2a Tensiometry: Tensiometric measurements of} $\gamma$ were taken with a calibrated du Nouy tensiometer (Kruss, Germany) by the ring detachment technique. $10 \mathrm{~mL}$ gelatin solution of desired concentration (or pure buffer solution for dilution experiments) was taken in a thermostated (accuracy within $\pm 0 \cdot 1 \mathrm{~K}$ ) double walled container at the requisite temperature into which a stock surfactant solution of desired concentration $(\sim 10-16$ times $\mathrm{cmc})$ was step-wise added (as required) with a Hamilton microsyringe allowing 20 min equilibration time after each addition followed by the measurement of $\gamma$. The detailed procedure can be found in earlier reports. ${ }^{18,49}$ Duplicate measurements were taken to check reproduci- 
bility. The $\gamma$ values were accurate within $\pm 0.1 \mathrm{mN} \mathrm{m}^{-1}$ and were corrected following the principles of Harkins and Jordan. ${ }^{52}$

\section{2b Conductometry: The conductivity meas-} urements were performed with a Jenway (UK) conductometer using a cell of unit cell constant. The same procedure as in tensiometry of addition of a stock concentrated surfactant solution $(\sim 10-30$ times $\mathrm{cmc}$ ) to $10 \mathrm{~mL}$ gelatin solution or buffer solution at $303 \mathrm{~K}$ (accurate within $\pm 0.1 \mathrm{~K}$ ) was followed. After ensuring thorough mixing and temperature equilibration, the specific conductance $(\kappa)$ was measured. The accuracy of the measurements was within $\pm 1 \%$. The measurement details can be found in our earlier reports. ${ }^{53,54}$

\section{2c Spectrophotometry: (i) Turbidimetry-Mea-} surements were taken in an UV-visible spectrophotometer (model 1601 of Shimadzu, Japan) operating in dual beam mode using a matched pair of quartz cuvettes of path length $1 \mathrm{~cm}$ under thermostated condition at $303 \pm 0 \cdot 1 \mathrm{~K}$. The buffer solution was used as the control. The amphiphile stock solution (at $\sim 4-6$ times $\mathrm{cmc}$ ) was then progressively added with a Hamilton microsyringe in the sample cell (consisting of $2.5 \mathrm{~mL}$ gelatin solution of desired strength) as required, and the solution was stirred well for mixing and allowed 5 min for equilibration. The spectral measurements were taken in the percent transmittance mode $(\% \mathrm{~T})$ in the wavelength range of $200-700 \mathrm{~nm}$. Turbidity index $(100-\%$ T at $264 \mathrm{~nm})$ was plotted against [surfactant]. At this $\lambda$, pure gelatin produced a shoulder in the spectra. The measured absorbance values were corrected for blank absorbance corresponding to the dilution of protein by the buffer solution. The measurement details can be found in our earlier report. ${ }^{54}$

(ii) Fluorimetry - The fluorimetric measurements were taken in Fluoromax-P, Horiba Jobin Yvon (USA) fluorimeter using a fluorescence quartz cuvette of path length $1 \mathrm{~cm}$. Experimental procedure was similar to that of turbidimetry excepting that here both gelatin and the stock surfactant solution contained $1.5 \mu \mathrm{M}$ pyrene. The procedure details can be found in literature. ${ }^{15}$ The emission spectra of pyrene was scanned from 350 to $450 \mathrm{~nm}$ after excitation at $335 \mathrm{~nm}$ allowing an excitation and emission slit width of $5 \mathrm{~nm}$, a wave length increment of $1.0 \mathrm{~nm}$ and an integration time of $0.10 \mathrm{~s}$. The ratio of the fluorescence intensities at the vibrational peaks of $I_{3}$ and $I_{1}$ in the emission spectra were then plotted against [surfactant].

\section{$2.2 \mathrm{~d}$ Isothermal titration calorimetry (ITC)}

The OMEGA ITC microcalorimeter of Microcal, Northampton (MA, USA) was used for thermometric measurements. A concentrated solution of the surfactant taken in the $350 \mu \mathrm{L}$ microsyringe was added for an injection duration of $30 \mathrm{~s}$ to $1.325 \mathrm{~mL}$ of gelatin solution (taken in the calorimeter cell) at equal intervals of $240 \mathrm{~s}$ in multiple steps (32-42 additions) under constant stirring $(350 \mathrm{rpm})$ condition. An identical gelatin solution $(1.645 \mathrm{~mL})$ was taken in the reference cell. The heat released at each step of interaction of the surfactant with gelatin was recorded and the enthalpy per mole of surfactant added was calculated with the ITC Microcal Origin 2.9 inbuilt software. The experiment of dilution of buffered amphiphile was also performed with the same injection matrix as that of the interaction experiment, taking aqueous buffer solution both in the reference and titration compartments of the cell. The enthalpy of the dilution $\left(\Delta H_{\mathrm{d}}\right)$ or net enthalpy of interaction (interaction-dilution, $\Delta H_{\mathrm{i}-\mathrm{d}}$ ) process was then plotted against [surfactant]. Each run was duplicated to check reproducibility. Water was circulated within the calorimeter by a NESLAB RTE100 bath at a temperature lower within five degree of the experimented temperature. The temperature in the cell compartment of the calorimeter was automatically scanned up to the desired temperature of measurement and adjusted with an accuracy of $\pm 0.01 \mathrm{~K}$.

\section{Results and discussion}

\section{$3.1 C_{16}$ chain containing cationic surfactants}

The cationic surfactants used are analogues of cetylammonium bromide (CAB). They resulted either by replacing hydrogen(s) by methyl group(s) or ethanolic $\left(\mathrm{CH}_{2} \mathrm{CH}_{2} \mathrm{OH}\right)$ group(s) or both (scheme 1 categorizes them as Group A and Group B surfactants). Group A consists of the compound $N$-cetyl$N, N, N$-trimethylammonium bromide $\left(\mathrm{CM}_{3} \mathrm{AB}\right)$ and its analogues $N$-cetyl- $N, N$-dimethyl- $N$-ethanoylammonium bromide $\left(\mathrm{CEM}_{2} \mathrm{AB}\right)$ and $N$-cetyl- $N, N$ diethanoyl- $N$-methylammonium bromide $\left(\mathrm{CE}_{2} \mathrm{MAB}\right)$. The Group B representatives are $N$-cetylammonium 
bromide (CAB), $\quad N$-cetyl- $N$-ethanoylammonium bromide (CEAB), $N$-cetyl- $N, N$-diethanoylammonium bromide $\left(\mathrm{CE}_{2} \mathrm{AB}\right)$ and $N$-cetyl- $N, N, N$-triethanoylammonium bromide $\left(\mathrm{CE}_{3} \mathrm{AB}\right)$. The $\mathrm{CE}_{3} \mathrm{AB}$ product may thus be synthesized both from $\mathrm{CM}_{3} \mathrm{AB}$ and $\mathrm{CAB}$. The surfactants have high solubility in water excepting $\mathrm{CAB}$ and $\mathrm{CEAB}$ which have shown fairly low solubility. Micellization of these surfactants in non-buffered aqueous solution have been reported earlier. $^{49,51}$

\subsection{Amphiphilic head group behaviours at different $p H$}

There were reports on the effect of varying chain length $^{55-58}$ or counterion $^{59,60}$ on the $\mathrm{cmc}$ of surfactants, but studies on the effect of varying head groups on the cmc of surfactants have been of less preponderance. ${ }^{61}$ Since in the present experiments, different pHs, 5.4, 6.5 and 9.0 have been used, the effect of $\mathrm{pH}$ on the ionization of the hydroxyl groups of the studied surfactants need to be addressed. The Group B surfactants CAB, CEAB and

Group A

\begin{tabular}{|c|c|}
\hline \multicolumn{2}{|c|}{$\underset{\mathrm{CH}_{3}}{\mathrm{Rr}^{-}} \stackrel{\mathrm{CH}_{3}}{\mathrm{CH}_{3}}$} \\
\hline \multicolumn{2}{|c|}{$\mathrm{CM}_{3} \mathrm{AB}[N$-hexadecyl- $N, N, N$-trimethylammonium bromide $]$} \\
\hline$\underset{\mathrm{CH}_{3}}{\mathrm{Rr}^{-}+\cdots} \overbrace{\mathrm{CH}}^{+}$ & 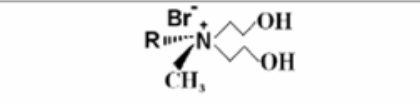 \\
\hline $\begin{array}{l}\mathrm{CEM}_{2} \mathrm{AB}[N \text {-hexadecyl- } N-(2- \\
\text { hydroxyethyl)- } N, N- \\
\text { dimethylammonium bromide }]\end{array}$ & $\begin{array}{c}\mathrm{CE}_{2} \mathrm{MAB}[N \text {-hexadecyl- } N, N \text {-bis }(2- \\
\text { hydroxyethyl)- } N \text { - } \\
\text { methylammonium bromide }]\end{array}$ \\
\hline \multicolumn{2}{|l|}{ Group B } \\
\hline 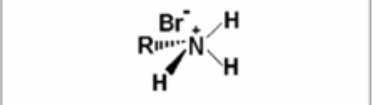 & 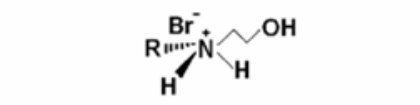 \\
\hline $\begin{array}{c}\mathrm{CAB}[N \text {-hexadecylammonium } \\
\text { bromide }]\end{array}$ & $\begin{array}{c}\text { CEAB }[N \text {-hexadecyl- } N \text { - }(2- \\
\text { hydroxyethyl)ammonium bromide })\end{array}$ \\
\hline${ }_{\mathrm{H}^{\mathrm{R}}}^{\mathrm{Br}} \mathrm{N}_{\mathrm{OH}}^{\mathrm{O}}$ & $\sum_{\mathrm{OH}}^{\mathrm{Br}^{-}} \underbrace{\mathrm{OH}}_{\mathrm{OH}}$ \\
\hline $\begin{array}{l}\mathrm{CE}_{2} \mathrm{AB}[N \text {-hexadecyl- } N, N \text {-bis }(2- \\
\text { hydroxyethyl)ammonium } \\
\text { bromide }]\end{array}$ & $\begin{array}{l}\mathrm{CE}_{3} \mathrm{AB}[N \text {-hexadecyl- } N, N, N \text {-tris }(2- \\
\text { hydroxyethyl)ammonium bromide }]\end{array}$ \\
\hline
\end{tabular}

Scheme 1. Surfactants used in the present work.
$\mathrm{CE}_{2} \mathrm{AB}$ contain three, two and one hydrogen(s) at the positively charged ammonium head group respectively. At $\mathrm{pH} 9.0$, they act as an acid, discharge $\mathrm{H}^{+}$(in solution) and neutral conjugate base species, which is insoluble at the above said $\mathrm{pH}$. Since such a provision of deprotonation is not possible either for Group A surfactants (since the ammonium head group are all methyl substituted) or $\mathrm{CE}_{3} \mathrm{AB}$ (containing three ethanolic groups), the question of insolubility does not arise. ${ }^{6-8}$ The Group B surfactants are, therefore, not studied at $\mathrm{pH} 9.0$. It may be mentioned that for all the amphiphilic species, $\gamma_{\mathrm{cmc}}$ decreases with $\mathrm{pH}$.

The head group dependent surface chemical and self aggregation properties of the two groups of surfactants at all the three pHs 5.4, 6.5 and 9.0 are comprehensively presented and discussed below with reference to table 1. The cmc's of Group A surfactants determined by different methods (surface tension, conductometry and microcalorimetry) are consistent. The observed $\mathrm{cmc}$ decreases by the increasing presence of the ethanolic group in the head at all the pHs (depiction at pH 9 in figure la). For the Group $\mathrm{B}$, at all pHs the cmc follows the order $\mathrm{CE}_{2} \mathrm{AB}<\mathrm{CE}_{3} \mathrm{AB}<\mathrm{CAB}<<\mathrm{CEAB}$. Only tensiometric method is used for the study (not illustrated). The $\gamma_{\mathrm{cmc}}$ values of each group of surfactants are nearly independent of their head group types. Their average magnitude at $\mathrm{cmc}$ is greater for Group A than for Group B. Thus the Group B representatives are more surface active than Group A species. The $A_{\min }$ and $\Gamma_{\max }$ (complimentary to each
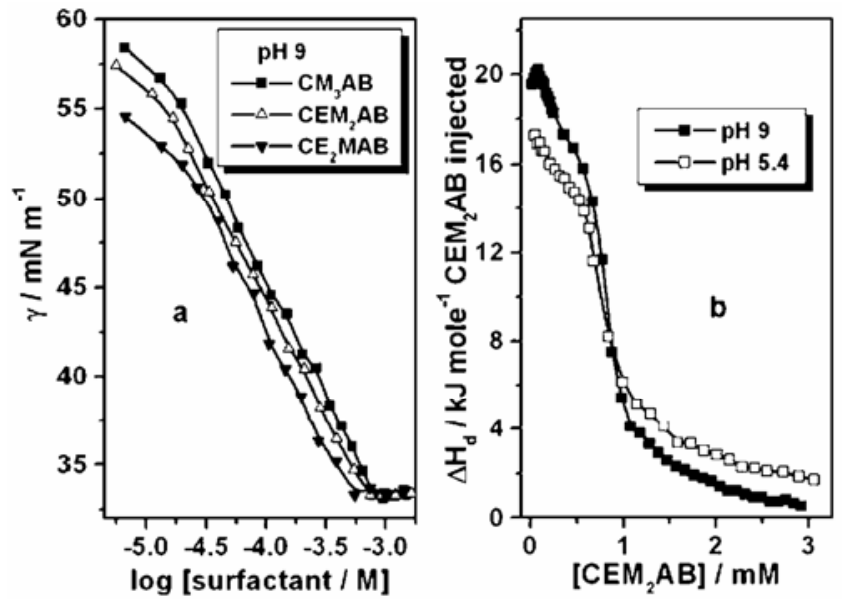

Figure 1. Tensiometric and microcalorimetric profiles of pure surfactants at $303 \mathrm{~K}$. (a) tensiometric plots for Group A surfactants at $\mathrm{pH} 9.0$; (b) enthalpograms of $\mathrm{CEM}_{2} \mathrm{AB}$ at $\mathrm{pH} 9.0$ and 5.4. 
Table 1. Interfacial and bulk parameters of Group A and B surfactants at $\mathrm{pH} 5 \cdot 4,6 \cdot 5$ and 9.0. ${ }^{\mathrm{a}}$

\begin{tabular}{|c|c|c|c|c|c|c|c|c|c|c|c|}
\hline \multirow[b]{2}{*}{$\mathrm{pH}$} & \multirow[b]{2}{*}{ System } & \multicolumn{3}{|c|}{$\mathrm{cmc}$} & \multicolumn{4}{|c|}{ Interfacial adsorption parameters } & \multicolumn{3}{|c|}{ Bulk properties } \\
\hline & & ST & Cond & Mcal & $\gamma_{\mathrm{cmc}}$ & $10^{7} \Gamma_{\max }$ & $A_{\min }$ & $-\Delta G_{\mathrm{ads}}^{\mathrm{o}}$ & $\beta$ & $-\Delta G_{\mathrm{m}}^{\mathrm{o}}$ & $-\Delta H_{\mathrm{m}}$ \\
\hline \multirow[t]{3}{*}{$9 \cdot 0$} & $\mathrm{CM}_{3} \mathrm{AB}$ & $0 \cdot 83$ & $0 \cdot 89$ & 0.95 & $33 \cdot 2$ & $11 \cdot 9$ & $1 \cdot 40$ & $74 \cdot 4$ & $0 \cdot 68$ & $46 \cdot 7$ & $8 \cdot 81$ \\
\hline & $\mathrm{CEM}_{2} \mathrm{AB}$ & 0.74 & 0.74 & $0 \cdot 64$ & $33 \cdot 3$ & $10 \cdot 8$ & $1 \cdot 54$ & $81 \cdot 2$ & $0 \cdot 60$ & $45 \cdot 2$ & $13 \cdot 9$ \\
\hline & $\mathrm{CE}_{2} \mathrm{MAB}$ & $0 \cdot 54$ & $0 \cdot 61$ & $0 \cdot 55$ & $33 \cdot 5$ & $10 \cdot 2$ & 1.63 & $81 \cdot 0$ & $0 \cdot 49$ & $43 \cdot 3$ & $15 \cdot 5$ \\
\hline \multirow[t]{7}{*}{$6 \cdot 5$} & $\mathrm{CM}_{3} \mathrm{AB}$ & $1 \cdot 06$ & $0 \cdot 99$ & 1.09 & $33 \cdot 5$ & $21 \cdot 4$ & 0.78 & - & $0 \cdot 67$ & $45 \cdot 5$ & $7 \cdot 79$ \\
\hline & $\mathrm{CEM}_{2} \mathrm{AB}$ & - & $0 \cdot 85$ & 0.91 & - & - & - & - & 0.70 & $47 \cdot 3$ & $15 \cdot 4$ \\
\hline & $\mathrm{CE}_{2} \mathrm{MAB}$ & - & 0.78 & 0.83 & - & - & - & - & 0.68 & $46 \cdot 9$ & $16 \cdot 8$ \\
\hline & $\mathrm{CAB}$ & $30 \cdot 2$ & - & - & $27 \cdot 0$ & $26 \cdot 8$ & $0 \cdot 62$ & $52 \cdot 7$ & - & $36 \cdot 3$ & - \\
\hline & CEAB & $98 \cdot 0$ & - & - & $24 \cdot 7$ & $18 \cdot 8$ & 0.88 & $58 \cdot 5$ & - & $33 \cdot 4$ & - \\
\hline & $\mathrm{CE}_{2} \mathrm{AB}$ & $18 \cdot 2$ & - & - & $26 \cdot 0$ & $23 \cdot 4$ & 0.71 & $57 \cdot 2$ & - & $37 \cdot 6$ & - \\
\hline & $\mathrm{CE}_{3} \mathrm{AB}$ & $21 \cdot 9$ & - & - & $26 \cdot 9$ & $22 \cdot 1$ & 0.75 & $57 \cdot 5$ & - & $37 \cdot 1$ & - \\
\hline \multirow[t]{7}{*}{$5 \cdot 4$} & $\mathrm{CM}_{3} \mathrm{AB}$ & 0.72 & 0.73 & 0.72 & $32 \cdot 7$ & $22 \cdot 9$ & 0.72 & $65 \cdot 3$ & 0.72 & $48 \cdot 7$ & $8 \cdot 84$ \\
\hline & $\mathrm{CEM}_{2} \mathrm{AB}$ & 0.54 & 0.67 & 0.63 & $32 \cdot 8$ & $20 \cdot 7$ & $0 \cdot 80$ & 65.7 & 0.61 & $46 \cdot 8$ & $11 \cdot 2$ \\
\hline & $\mathrm{CE}_{2} \mathrm{MAB}$ & $0 \cdot 46$ & 0.55 & 0.45 & $32 \cdot 5$ & $19 \cdot 4$ & $0 \cdot 86$ & $65 \cdot 8$ & 0.54 & $45 \cdot 4$ & $14 \cdot 0$ \\
\hline & $\mathrm{CAB}$ & $26 \cdot 9$ & - & - & $24 \cdot 8$ & $29 \cdot 1$ & 0.57 & $52 \cdot 8$ & - & $36 \cdot 6$ & - \\
\hline & CEAB & $79 \cdot 4$ & - & - & $24 \cdot 0$ & $22 \cdot 2$ & 0.75 & $55 \cdot 5$ & - & $33 \cdot 9$ & - \\
\hline & $\mathrm{CE}_{2} \mathrm{AB}$ & $14 \cdot 1$ & - & - & $24 \cdot 5$ & $25 \cdot 3$ & 0.66 & $57 \cdot 0$ & - & $38 \cdot 2$ & - \\
\hline & $\mathrm{CE}_{3} \mathrm{AB}$ & $20 \cdot 4$ & - & - & $25 \cdot 4$ & $23 \cdot 8$ & $0 \cdot 70$ & $56 \cdot 9$ & - & $37 \cdot 3$ & - \\
\hline
\end{tabular}

${ }^{\mathrm{a}} \mathrm{cmc}, \gamma_{\mathrm{cmc}}, \Gamma_{\max }$ and $A_{\min }$, are in $\mathrm{mM}$ (for Group A surfactants) and $\mu \mathrm{M}$ (for Group B surfactants), $\mathrm{mN} \mathrm{m}^{-1}, \mathrm{~mol} \mathrm{~m}^{-2}$ and $\mathrm{nm}^{2}$ molecule ${ }^{-1}$ respectively; $\Delta G_{\mathrm{ads}}^{\mathrm{o}}, \Delta G_{\mathrm{m}}^{\mathrm{o}}, \Delta H_{\mathrm{m}}$ and are all in $\mathrm{kJ} \mathrm{mol}^{-1}$. Standard deviations in $\mathrm{cmc}, \gamma_{\mathrm{cmc}}, \Gamma_{\max }, \mathrm{A}_{\min }, f$, $\Delta G_{\mathrm{m}}^{\mathrm{o}}$ and $\Delta H_{\mathrm{m}}$ are $\pm 2, \pm 5, \pm 3, \pm 5, \pm 3, \pm 7$ and $\pm 6 \%$, respectively.

other), depend on the substitution or the modification of the head groups of the two classes of surfactants studied here. They are evaluated using the equations, ${ }^{53,54,62,63}$

$$
\Gamma_{\max }=-1 /(2.303 n R T) \underset{[S] \sim \mathrm{cms}}{\mathrm{Lt}} d \gamma / d \log [S]
$$

and

$$
A_{\min }=10^{18} / N_{\mathrm{A}} \Gamma_{\max } \text { in } \mathrm{nm}^{2} \text { molecule }{ }^{-1},
$$

where $n, R, T,[S]$ and $N_{A}$ are the number of species formed per surfactant monomer in solution (it was 2 for the surfactants by ionization), the universal gas constant, the absolute temperature, the molar concentration of the surfactant in solution and the Avogadro number, respectively. Here concentration is used in place of activity, as the solutions in use are fairly dilute. The substitution of an ethanolic group for either one $-\mathrm{CH}_{3}$ in the head group of $\mathrm{CM}_{3} \mathrm{AB}$ (Group A) or one-H in the head group of CAB (Group B) produces large changes in the interfacial parameters. The second and third substitutions produce moderate changes. The substitution decreases the head groups' affinity for the counterions in the Group A species at $\mathrm{pH} \mathrm{9.0} \mathrm{and} \mathrm{5.4,} \mathrm{as} \mathrm{found}$ from the declining magnitudes of the extent of counterion binding $(\beta)$, evaluated following the relation, $\beta=1-\left(\mathrm{S}_{2} / \mathrm{S}_{1}\right){ }^{64,65}$ The conductance and the calorimetric methods are insensitive to elucidate $\beta$ and the standard enthalpy change for micellization, $\Delta H_{\mathrm{m}}^{\circ}$, respectively for the Group B compounds. The trends in the cmc were reflected on the standard Gibbs free energy of micellization, $\Delta G_{\mathrm{m}}^{\mathrm{o}}$ (estimated following earlier reported protocols ${ }^{53,54,63} \quad \Delta G_{\mathrm{m}}^{\mathrm{o}}=(1+\beta)$ $R T \ln X_{\mathrm{cmc}}$, where $X_{\mathrm{cmc}}$ is the cmc of the pure surfactant in the mole fraction scale at temperature $T$ ). The $\Delta H_{\mathrm{m}}^{\mathrm{o}}$, becomes more exothermic with increased substitutions in the Group A surfactants. The phenomenon of micellization is generally entropy controlled at lower temperature, whereas at higher temperature, it is enthalpy controlled. ${ }^{66}$ The first substitution produces comparatively large enthalpy change. The trends in the properties discussed are also dependent on $\mathrm{pH}$; a slight decrease in the $\Delta H_{\mathrm{m}}^{\circ}$ results with decrease in $\mathrm{pH}$ (figure $1 \mathrm{~b}$ ). The free energy of adsorption of the amphiphiles have been evaluated using the equation, ${ }^{6}$

$$
\Delta G_{\mathrm{ad}}^{\mathrm{o}}=\Delta G_{\mathrm{m}}^{\mathrm{o}}-\left(\pi_{\mathrm{cmc}} / \Gamma_{\max }\right)
$$

where $\pi_{\mathrm{cmc}}=\gamma_{\text {water }}-\gamma_{\mathrm{cmc}}$. It is also presented in table 1. The $\Delta G_{\mathrm{ad}}^{\mathrm{o}}$ is greater than that of $\Delta G_{\mathrm{m}}^{\mathrm{o}}$ for all the 
systems at all $\mathrm{pH}$. Their difference is a measure of the spontaneity difference of the two processes; the adsorption process is fairly stronger than the bulk process of micellization. Thus, the head group architecture of the surfactants play a decisive role in the $\mathrm{pH}$ dependent surface chemical behaviours of the surfactants.

The factors responsible for the self-aggregation of the surfactants in solution are solubility, steric repulsion and shielding of the head group charge. The Group B compounds have lower solubilities than the Group A compounds; the former produces cmc's of magnitudes one order lower than the latter. It is seen that the weakly soluble $N$-octyl- $N, N, N$-trimethylammonium bromide $\left(\mathrm{OM}_{3} \mathrm{AB}\right)$ produces cmc values comparable with the Group B surfactants. ${ }^{67}$ The addition of ethanolic group on the amphiphile head has two opposing effects on the cmc. It decreases the cmc due to the shielding of the charged head group to interact with its neighbours. Also it enhances the $\mathrm{cmc}$ by the steric repulsions among the ethanolic groups of the neighbouring amphiphiles. Thus, the numbers of the ethanolic groups present in the head plays a positive role on the amphiphile selfaggregation. Methyl group imparts more steric restriction than hydrogen. Thus, the $\mathrm{cmc}$ of the Group A surfactants are greater than Group B. A decrease in the cmc among the Group A members with increasing number of ethanolic substitution is thus a result of shielding of the positively charged $\mathrm{N}$ centre. Increase in the steric repulsion (due to additional methyl or ethanolic groups) in the matter of $\mathrm{cmc}$ increase with increased substitution is considered minor. The charge shielding effectivity of the ethanolic group(s) in both is considered equivalent. The factors mentioned above play a competing role towards their interfacial and bulk behaviours. The $A_{\text {min }}^{\mathrm{CAB}}<A_{\min }^{\mathrm{CM}_{3} \mathrm{AB}}$ whereas substitution of one ethanolic group in $\mathrm{CAB}$ or $\mathrm{CM}_{3} \mathrm{AB}$ causes $A_{\min }^{\mathrm{CEAB}} \gg A_{\min }^{\mathrm{CAB}}$ and $A_{\min }^{\mathrm{CEM}_{2} \mathrm{AB}} \gg A_{\min }^{\mathrm{CM}_{3} \mathrm{AB}}$, but further substitution yielding $\mathrm{CE}_{2} \mathrm{MAB}$ and $\mathrm{CE}_{3} \mathrm{AB}$ enhances the head group area for the Group A surfactants mildly: thus, $A_{\text {min }}^{\mathrm{CM}_{3} \mathrm{AB}}<A_{\text {min }}^{\mathrm{CEM}_{2} \mathrm{AB}}<A_{\min }^{\mathrm{CE}_{2} \mathrm{MAB}}$ with no such significant variation for the Group B surfactants where $A_{\min }^{\mathrm{CEAB}}>A_{\min }^{\mathrm{CE}_{2} \mathrm{AB}} \approx A_{\min }^{\mathrm{CE}_{3} \mathrm{AB}}$. Such a variation in the latter series is due to the reduction in the area of exclusion when substituted with more than one ethanolic group. Intramolecular hydrogen bonding among the multiple ethanolic substitutions is also effective in both $\mathrm{CE}_{2} \mathrm{AB}$ and $\mathrm{CE}_{3} \mathrm{AB}$ with a resultant decrease in the area. In the concentration region fairly less than cmc, the surface activity of $\mathrm{CE}_{2} \mathrm{MAB}$ at $\mathrm{pH} 9$ is greater than that at $\mathrm{pH} 5.4$ (figure 2) which is the trend for the other analogues in the group (table 1). The head group charge density is less at $\mathrm{pH} 5.4$ favouring a close association among the charged head groups. The $\beta$ values have a decreasing trend with increasing ethanolic substitution at $\mathrm{pH} 9$ and 5.4; which is only marginal at $\mathrm{pH}$ 6.5. The micellization is more exothermic down the series at all $\mathrm{pH}$.

\subsection{Interfacial behaviour of gelatin}

Gelatin is a random coil polyampholyte with a persistence length of $\sim 20 \mathrm{~nm},{ }^{68,69}$ and the composite representation is (Gly-X-Pro $)_{n}$, in which $21 \%$ of the chain constitutes glycine, another $24 \%$ either proline or hydroxyproline (both non-polar residues), and $\mathrm{X}$ represents other amino acid residues. $\mathrm{X}$ mainly involves $13 \%$ basic groups such as lysine, histidine and arginine, $16 \%$ acidic groups such as glutamic and aspartic acid, other non-polar side chains constitute the rest $26 \%$. Thus, a significant portion of the chain is neutral leaving sparsely charged portion. ${ }^{70}$ The isoelectric $\mathrm{pH}$ of gelatin is 4.8. At $\mathrm{pH} 9.0$, nearly $16 \%$ of the chain is negatively charged. It declines significantly at $\mathrm{pH} 5 \cdot 4$.

Gelatin is a denatured protein and thus prefers to reside at the air-solution interface. It has been reported that surface activity of gelatin enhances with temperature and its concentration. ${ }^{49}$ At $\mathrm{pH} \mathrm{5.4}$, the non-polar fraction in the gelatin chain is greater than

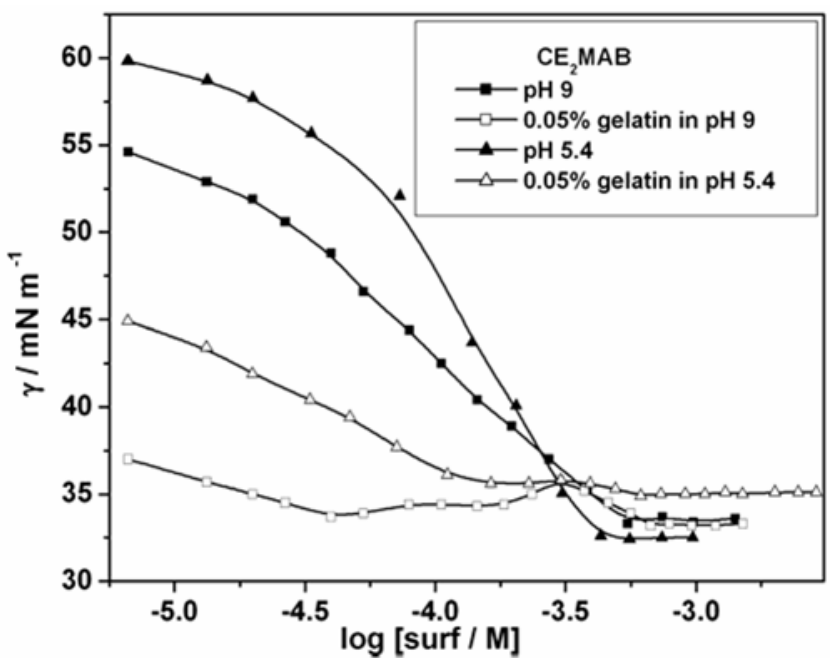

Figure 2. Tensiometric profiles of $\mathrm{CE}_{2} \mathrm{MAB}$ at $\mathrm{pH} 9 \cdot 0$ and 5.4 in presence and absence of gelatin at $303 \mathrm{~K}$. 
the polar counterparts. This makes the chain appreciably hydrophobic and it prefers the interface yielding a decreased surface tension of $53.0 \mathrm{~m} \mathrm{~N} \mathrm{~m}^{-1}$. At $\mathrm{pH}$ 9.0, the biopolymer is obviously less hydrophobic to produce increased surface tension $\left(58.3 \mathrm{mN} \mathrm{m}^{-1}\right)$ of its aqueous solution.

\subsection{Gelatin-amphiphile interaction: A schematic illustration with reference to $C M_{3} A B$ as a representative}

Since at higher $\mathrm{pH}$, Group B amphiphiles have poor solubility than Group A amphiphiles, measurements of their interaction are taken only at the lower $\mathrm{pH}$ 5.4. Subsequent discussion results of Group A surfactants at the $\mathrm{pH} 9.0$ and 5.4 and for Group B surfactants at $\mathrm{pH} 5.4$ only are considered.

3.4a At pH 9.0: A synopsis of the said interaction taking gelatin- $\mathrm{CM}_{3} \mathrm{AB}$ combination as a case is presented below with reference to results illustrated in figure 3 for the $\mathrm{CM}_{3} \mathrm{AB}$. Cationic surfactants like $\mathrm{CM}_{3} \mathrm{AB}$ and $\mathrm{OM}_{3} \mathrm{AB}$, etc. interact with gelatin (G) forming composition dependent products at the interface and in the bulk. ${ }^{49,50}$ Initially, monomeric $\mathrm{CM}_{3} \mathrm{AB}$ binds to the negative sites on the gelatin at a basic $\mathrm{pH} 9.0$ at the interface $\left(\mathrm{G}^{\mathrm{I}}\right)$ to form an interfacially adsorbed species $\mathrm{GS}_{\mathrm{n}}^{1}$, resulting an initial decrease in the surface tension till $\mathrm{T}_{1}$ following the process A,

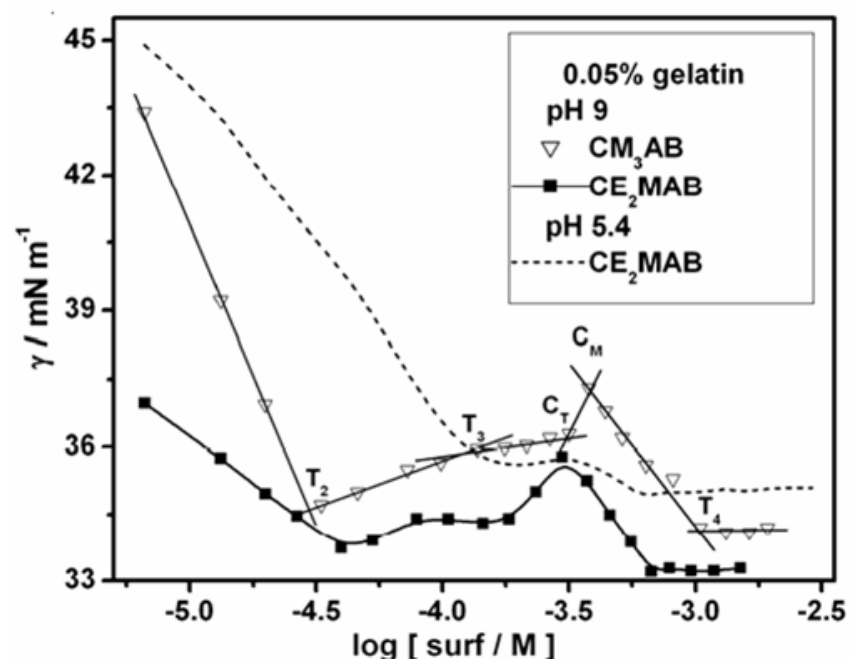

Figure 3. Tensiometric profiles of Group A and B surfactants in $0.05 \%$ gelatin. $\mathrm{CM}_{3} \mathrm{AB}$ and $\mathrm{CE}_{2} \mathrm{MAB}$ at $\mathrm{pH}$ 9.0. Profile of $\mathrm{CE}_{2} \mathrm{MAB}$ on $0.05 \%$ gelatin at $\mathrm{pH} 5.4$ is shown for comparison. The break points are identified with symbols defined in the text.

$$
\mathrm{G}^{\mathrm{I}}+\mathrm{nS} \rightarrow \mathrm{GS}_{\mathrm{n}}^{1}, \quad \text { (Process A or PA). }
$$

Further addition of CTAB causes the $\mathrm{CTA}^{+}$species to favorably combine with gelatin in the bulk $\left(\mathrm{G}^{\mathrm{B}}\right)$,

$$
G^{\mathrm{B}}+\mathrm{nS} \rightarrow \mathrm{GS}_{\mathrm{n}}^{\mathrm{B}} \text { (surface inactive complex) }
$$

(Process $\mathrm{A}^{\prime}$ or $\mathrm{PA}^{\prime}$ )

thereby arresting the decline in $\gamma\left(T_{1}-T_{2}\right.$ regime $)$. This feature is only observable at gelatin concentration greater than $0.05 \%$.

At a critical concentration (termed critical aggregation concentration cac or $T_{2}$ ), specific for each variety of surfactant, the local concentration of the monomers bound to the polymeric chain reaches its saturation. Then amphiphile monomers start to associate to form small induced micelles that bind with $\mathrm{GS}_{\mathrm{n}}^{1}$ forming gelatin-micelle complex or $\mathrm{GS}_{\mathrm{m}}^{\mathrm{B}}$

$$
\mathrm{GS}_{\mathrm{n}}^{1}+\mathrm{CTAB} \text { (aggregates) } \rightarrow \mathrm{GS}_{\mathrm{m}}^{\mathrm{B}}
$$

(Process B or PB).

The tiny micelles adhere to the biopolymer chain and the complex becomes soluble in the bulk to get transformed into $\mathrm{GS}_{\mathrm{m}}^{\mathrm{B}}$. Replenishment of the relieved interface (I) by the pure surfactant monomer also takes place simultaneously following the process,

$$
\mathrm{I}+\mathrm{xCTAB} \rightarrow \mathrm{I}(\mathrm{CTAB})_{\mathrm{X}} \quad \text { (Process } \mathrm{C} \text { or PC). }
$$

The two processes $\mathrm{B}$ and $\mathrm{C}$ take place in concurrence. If they compensate each other $\gamma$ remains nonvariant with [amphiphile]. If the process $B$ exceeds the process $\mathrm{C}$, free surface is created with a net increase in $\gamma$. If otherwise, $\gamma$ decreases. In the present system, there is more or less equivalent compensation with a slightly greater contribution of the process B from $T_{2}$ showing a shallow rise in $\gamma$ till $T_{3}$. A broad plateau is observed thereafter, when the two processes more or less compensate each other. The bulk concentration of $\mathrm{GS}_{\mathrm{m}}^{\mathrm{B}}$ becomes large with an onset of precipitation, termed as the coacervation at $C_{T}$ with the formation of $\mathrm{GS}_{\mathrm{m}}^{\mathrm{C}}$ following the equilibrium,

$$
\mathrm{yGS} S_{\mathrm{m}}^{\mathrm{B}} \leftrightarrow\left(\mathrm{GS}_{\mathrm{m}}^{\mathrm{B}}\right)_{\mathrm{y}} \quad \text { or } \quad \mathrm{GS}_{\mathrm{m}}^{\mathrm{C}}
$$

(Process D or PD).

Phase separation of $\mathrm{GS}_{\mathrm{m}}^{\mathrm{C}}$ induces formation of a narrow 'hump' at the higher concentration end of the plateau. The turbidity attains maximum at the hump $\left(\mathrm{C}_{\mathrm{M}}\right)$. On further surfactant addition, the surfactant 
monomers are adsorbed at the interface to decrease $\gamma$. After interfacial saturation at $T_{4}$, free larger micelle formation occurs (with extended $\mathrm{cmc}$ ) in solution. Thus, $\gamma$ attains a constant value, i.e. $\gamma_{\mathrm{cmc}}$ at the second plateau. The out of phase $\mathrm{GS}_{\mathrm{m}}^{\mathrm{C}}$ (agglomerated complex) disintegrates beyond $\mathrm{T}_{4}$, and gradually gets a hydrophobic environment within the micellar core to become solubilized with decrease in turbidity to produce clarity in solution following the process E.

$$
\begin{aligned}
& \mathrm{GS}_{\mathrm{m}}^{\mathrm{C}}+\text { free } \mathrm{CTAB} \text { micelle } \leftrightarrow \mathrm{GS}_{\mathrm{m}}(\mathrm{CTAB})_{\mathrm{MS}} \\
& \quad \text { (soluble) + free CTAB micelle }
\end{aligned}
$$

(Process E or PE).

3.4b At pH 5.4: At pH 5.4, the negative binding sites for the biopolymer are smaller in number compared to that at $\mathrm{pH} 9 \cdot 0$. The formation of $\mathrm{GS}_{\mathrm{n}}^{1}$ at $\mathrm{pH}$ 5.4 is less than that at $\mathrm{pH} 9 \cdot 0$. The $\gamma$ vs $\log$ [surfactant] plots for the former are, therefore, of higher altitude than the latter. In the presence of gelatin at $\mathrm{pH} 9 \cdot 0$, two maxima (the second in the form of a hump) are observed (figure 3) both for $\mathrm{CM}_{3} \mathrm{AB}$ and $\mathrm{CE}_{2} \mathrm{MAB}$. At $\mathrm{pH} 5 \cdot 4$, there appears only one maximum, and the initial rise is fairly flat. The formation of the coacervates and hence the associated turbidity is less. The formation of the hump (at $\mathrm{pH} 9.0$ for amphiphile coprecipitation with the

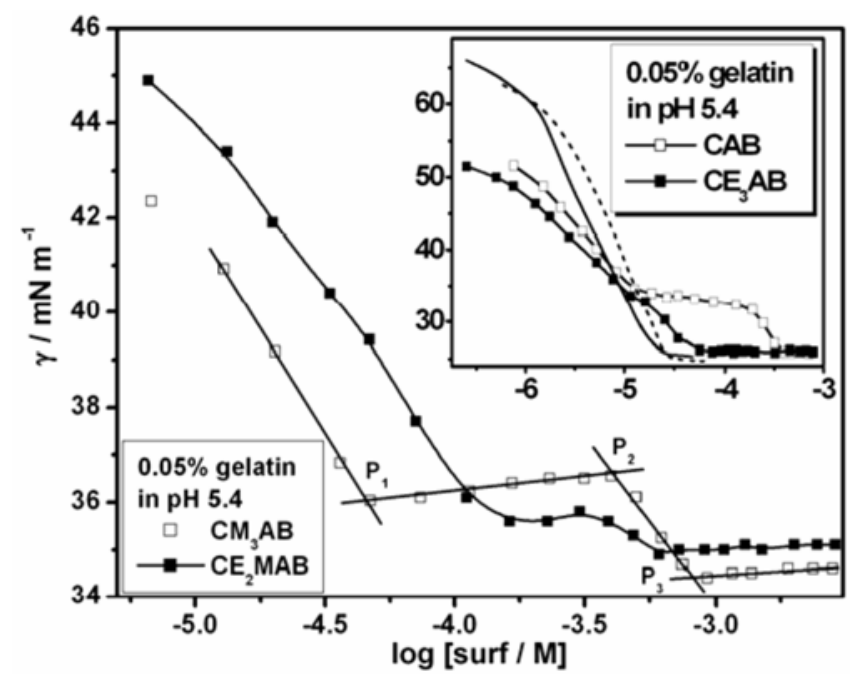

Figure 4. Tensiometric interaction profile of Group A and $B$ surfactants in $0.05 \%$ gelatin at $\mathrm{pH} 5.4$. Main plot: For $\mathrm{CM}_{3} \mathrm{AB}$ and $\mathrm{CE}_{2} \mathrm{MAB}$ at $303 \mathrm{~K}$. Inset: For $\mathrm{CAB}$ and $\mathrm{CE}_{3} \mathrm{AB}$. Broken and solid line represents $\mathrm{CAB}$ and $\mathrm{CE}_{3} \mathrm{AB}$, respectively in pure buffer medium ( $\left.\mathrm{pH} 5 \cdot 4\right)$. The break points in the main plot are identified with symbols defined in the text. coacervate) is thus absent. To differentiate between the two properties, the break points in the curve in the main plot of figure 4 at $\mathrm{pH} 5.4$ are designated by ' $\mathrm{P}$ ' instead of ' $\mathrm{T}$ '. As the concentration of $\mathrm{GS}_{\mathrm{n}}^{1}$ is less at this $\mathrm{pH}$, the process $\mathrm{B}$ and $\mathrm{C}$ have comparable rates to produce a broad plateau between $\mathrm{P}_{1}$ and $\mathrm{P}_{2}$. $\mathrm{P}_{1}$ corresponds to the cac. The profile is very similar to that of weakly interacting systems. ${ }^{71}$ Only a slight coacervation occurs at intermediate concentration between $\mathrm{P}_{1}$ and $\mathrm{P}_{2}$. Dissolution starts soon on the addition of excess of the surfactant yielding a second plateau beyond $\mathrm{P}_{3}$ similar to that arises at $\mathrm{pH}$ 9.0.

\subsection{Influence of surfactant head group on gelatin-surfactant complexation}

It has been recently reported that formation of DNAcationic surfactant complexes is hardly affected by the surfactant head group architecture. ${ }^{17}$ The surfactants used there were to some extent common with that used here. But the observations on their interaction with gelatin do not fully comply with DNA. There is a report that calf thymus-DNA interaction with Group A surfactants is largely affected by the head group type. ${ }^{18}$ Primarily, the variation in the interaction profile arises from its influence on the local environment of the binding site in which the altered state of hydration by the presence of ethanolic groups may have a fare share. It corroborates fairly well with our results. The findings on the gelatin-surfactant systems with regard to the head group variation at $\mathrm{pH} 9.0$ and 5.4 are discussed below.

3.5a Group $A$ at $p H$ 9.0: Substitution of the methyl group by the ethanolic group increases the head group area of the Group A surfactants: the cationic centre becomes sterically hindered to approach the ionic sites of gelatin. In spite of easier amphiphile self-aggregation due to the ethanolic substitution, steric effect defers the formation of the cac. A delayed $T_{2}$ (cac) for the Group A species thus arises (table 2a). Such a delayed DNA-induced aggregation of the Group A surfactants were also observed before. ${ }^{18}$ As noted before, $\mathrm{T}_{2}$ appears in the tensiometric illustrations only, other methods fail to register its manifestation as also reported for other systems. ${ }^{49,54}$ At any particular concentration, the differences in the surface activities among the Group A surfactants are only moderate (figure la), whereas 
Table 2. The $T_{2}$ (cac), $T_{3}, C_{T}, C_{M}$ and $T_{4}\left(\mathrm{cmc}_{2}\right.$ ) (all in $\mathrm{mM}$ ) for the interaction of gelatin with Group A and $B$ surfactants at (a) $\mathrm{pH} 9.0$ and (b) 5.4 at $303 \mathrm{~K}^{\text {a }}$

(a)

\begin{tabular}{|c|c|c|c|c|c|c|c|c|c|c|c|}
\hline \multirow[b]{2}{*}{ pH 9.0 } & \multicolumn{3}{|c|}{ Surface tension } & \multicolumn{2}{|c|}{ Cond } & \multicolumn{2}{|c|}{ Mcal } & \multicolumn{2}{|c|}{ UV } & \multicolumn{2}{|c|}{ FL } \\
\hline & $\begin{array}{c}\mathrm{T}_{2} \\
(\mathrm{cac})\end{array}$ & $\begin{array}{c}\mathrm{T}_{3} \\
{\left[\mathrm{C}_{\mathrm{T}}, \mathrm{C}_{\mathrm{M}}\right]}\end{array}$ & $\begin{array}{c}\mathrm{T}_{4} \\
{\left[\mathrm{C}_{\mathrm{B}}\right]}\end{array}$ & $\begin{array}{c}\mathrm{T}_{3} \\
{\left[\mathrm{C}_{\mathrm{T}}\right]}\end{array}$ & $\mathrm{T}_{4}$ & $\begin{array}{c}\mathrm{T}_{3} \\
{\left[\mathrm{C}_{\mathrm{T}}\right]}\end{array}$ & $\begin{array}{c}\mathrm{T}_{4} \\
{\left[\mathrm{C}_{\mathrm{B}}\right]}\end{array}$ & $\begin{array}{c}\mathrm{T}_{3} \\
{\left[\mathrm{C}_{\mathrm{T}}\right]}\end{array}$ & $\mathrm{T}_{4}$ & $\begin{array}{c}\mathrm{T}_{3} \\
{\left[\mathrm{C}_{\mathrm{T}}\right]}\end{array}$ & $\begin{array}{c}\mathrm{T}_{4} \\
{\left[\mathrm{C}_{\mathrm{B}}\right]}\end{array}$ \\
\hline $\mathrm{CM}_{3} \mathrm{AB}$ & 0.03 & $\begin{array}{c}0 \cdot 14 \\
{[0 \cdot 32,0 \cdot 38]}\end{array}$ & $\begin{array}{c}1 \cdot 04 \\
{[0 \cdot 45]}\end{array}$ & $\begin{array}{c}0 \cdot 14 \\
{[0 \cdot 35]}\end{array}$ & 1.22 & $\begin{array}{c}0 \cdot 15 \\
{[0 \cdot 33]}\end{array}$ & $\begin{array}{c}1 \cdot 20 \\
{[0 \cdot 61]}\end{array}$ & $\begin{array}{c}0 \cdot 14 \\
{[0 \cdot 32]}\end{array}$ & $1 \cdot 14$ & $\begin{array}{c}0 \cdot 12 \\
{[0 \cdot 35]}\end{array}$ & $\begin{array}{c}1.02 \\
{[0 \cdot 49]}\end{array}$ \\
\hline $\mathrm{CEM}_{2} \mathrm{AB}$ & 0.038 & $\begin{array}{c}0.09 \\
{[0 \cdot 28,0 \cdot 36]}\end{array}$ & $\begin{array}{c}0.79 \\
{[0 \cdot 44]}\end{array}$ & $\begin{array}{c}0 \cdot 08 \\
{[-]}\end{array}$ & $0 \cdot 81$ & $\begin{array}{c}0.09 \\
{[-]}\end{array}$ & $\begin{array}{c}0.98 \\
{[0 \cdot 60]}\end{array}$ & $\begin{array}{c}0.08 \\
{[0 \cdot 34]}\end{array}$ & $0 \cdot 87$ & $\begin{array}{c}0.08 \\
{[0.27]}\end{array}$ & $\begin{array}{c}0.85 \\
{[0 \cdot 43]}\end{array}$ \\
\hline $\mathrm{CE}_{2} \mathrm{MAB}$ & 0.045 & $\begin{array}{c}0 \cdot 08 \\
{[0 \cdot 19,0 \cdot 30]}\end{array}$ & $\begin{array}{c}0 \cdot 71 \\
{[0 \cdot 38]}\end{array}$ & $\begin{array}{c}0 \cdot 06 \\
{[-]}\end{array}$ & 0.70 & $\begin{array}{c}0.07 \\
{[-]}\end{array}$ & $\begin{array}{c}0 \cdot 80 \\
{[0 \cdot 50]}\end{array}$ & $\begin{array}{c}0.05 \\
{[0.23]}\end{array}$ & 0.78 & $\begin{array}{c}0.06 \\
{[0 \cdot 23]}\end{array}$ & $\begin{array}{c}0.75 \\
{[0.39]}\end{array}$ \\
\hline
\end{tabular}

(b)

\begin{tabular}{|c|c|c|c|c|c|c|c|c|c|c|c|c|c|c|}
\hline \multirow[b]{2}{*}{ pH 5.4} & \multicolumn{3}{|c|}{ ST } & \multicolumn{2}{|c|}{ Cond } & \multicolumn{3}{|c|}{ Mcal } & \multicolumn{3}{|c|}{ UV } & \multicolumn{3}{|c|}{ FL } \\
\hline & $\mathrm{P}_{1}$ & $\mathrm{P}_{2}$ & $\mathrm{P}_{3}$ & $\mathrm{P}_{1}$ & $\mathrm{P}_{3}$ & $\mathrm{P}_{1}$ & $\mathrm{P}_{2}$ & $\mathrm{P}_{3}$ & $\mathrm{P}_{1}$ & $\mathrm{P}_{2}$ & $\mathrm{P}_{3}$ & $\mathrm{P}_{1}$ & $\mathrm{P}_{2}$ & $\mathrm{P}_{3}$ \\
\hline $\mathrm{CM}_{3} \mathrm{AB}$ & 0.046 & 0.44 & 0.82 & $0 \cdot 14$ & 0.90 & $0 \cdot 14$ & 0.56 & 0.86 & 0.12 & 0.43 & 0.83 & $0 \cdot 11$ & 0.43 & 0.95 \\
\hline $\mathrm{CEM}_{2} \mathrm{AB}$ & 0.078 & $0 \cdot 35$ & 0.72 & $0 \cdot 18$ & 0.79 & $0 \cdot 18$ & 0.46 & 0.68 & $0 \cdot 17$ & $0 \cdot 36$ & 0.70 & $0 \cdot 19$ & $0 \cdot 35$ & 0.69 \\
\hline $\mathrm{CE}_{2} \mathrm{MAB}$ & $0 \cdot 130$ & $0 \cdot 31$ & 0.62 & $0 \cdot 21$ & 0.68 & 0.22 & 0.38 & 0.60 & $0 \cdot 19$ & 0.30 & 0.63 & $0 \cdot 25$ & 0.31 & 0.60 \\
\hline CAB & 0.012 & $0 \cdot 20$ & $0 \cdot 34$ & - & - & - & - & - & 0.01 & 0.21 & $0 \cdot 30$ & - & - & - \\
\hline CEAB & 0.019 & $0 \cdot 17$ & 0.58 & - & - & - & - & - & 0.02 & $0 \cdot 14$ & 0.50 & - & - & - \\
\hline $\mathrm{CE}_{2} \mathrm{AB}$ & $0 \cdot 04$ & - & - & - & - & - & - & - & 0.03 & 0.09 & $0 \cdot 60$ & - & - & - \\
\hline $\mathrm{CE}_{3} \mathrm{AB}$ & 0.05 & - & - & - & - & - & - & - & 0.05 & 0.20 & $0 \cdot 69$ & - & - & - \\
\hline
\end{tabular}

${ }^{a}$ Standard deviations of the break points are in the range of $3-10 \%$.

appreciable divergences are observed for their interactions with the gelatin $\left(\mathrm{CM}_{3} \mathrm{AB}\right.$ and $\mathrm{CE}_{2} \mathrm{MAB}$ in figure 3). It is observed that substitution enhances the surface activity at any particular concentration. This may be explained as follows. Inter-association of $\mathrm{CH}_{2} \mathrm{CH}_{2} \mathrm{OH}$ groups enhances hydrophobicity of $\mathrm{GS}_{\mathrm{n}}^{1}$, the extent of substitution concomitantly enhances the process, and subsequently the surface activity. A similar interaction at the air-liquid interface between NaPSS and DTAB has been reported. ${ }^{72}$ The point $\mathrm{T}_{3}$ represents the stage at which the two processes $\mathrm{B}$ and $\mathrm{C}$ proceed at equal rates to yield a constant $\gamma$ (figure 3 ). The appearance of $T_{3}$ depends on the hydrophobicity of the amphiphile and the nature of its head group. On increasing the number of substitutions at the ammonium head group, an early formation of $T_{3}$ results: the slope of the graph in the lower concentration end of the $T_{2}$ is greater for the $\mathrm{CM}_{3} \mathrm{AB}$ compared with that of the $\mathrm{CE}_{2} \mathrm{MAB}$ (figure 3). Formation of relatively lower concentration of $\mathrm{GS}_{\mathrm{n}}^{1}$, and consequently a lower concentration of $\mathrm{GS}_{\mathrm{m}}^{\mathrm{B}}$ results an early occurrence of $T_{3}$ for $\mathrm{CE}_{2} \mathrm{MAB}$ than $\mathrm{CM}_{3} \mathrm{AB}$. Since the kinetics of a process depends on the concentration of the reactants, the rate of the process B for the substituted varieties is marginally greater than that of the process $\mathrm{C}$, and the two rates balance to result an early formation of $T_{3}$.

Fluorimetric $\left(I_{3} / I_{1}\right)$ profiles (figure 5$)$ are indicative of the extent of the hydrophobic microenvironment around the fluorophore, pyrene. The index increases upon the addition of $\mathrm{CM}_{3} \mathrm{AB}$ in gelatin solution up to $\mathrm{T}_{3}$ before forming a crest or plateau similar to that reported earlier. ${ }^{73}$ At any concentration, the polarity indexes of the ethoxylated compounds are more than that of $\mathrm{CM}_{3} \mathrm{AB}$ which further supports the enhancement of the hydrophobicity with substitution. The index forms a flat top plateau for the $\mathrm{CM}_{3} \mathrm{AB}$ at $\mathrm{C}_{\mathrm{T}}$, which gradually transforms to a crest in the case of $\mathrm{CE}_{2} \mathrm{MAB}$. A lower $\mathrm{GS}_{\mathrm{m}}^{\mathrm{B}}$ concentration results lowering of the $\mathrm{GS}_{\mathrm{m}}^{\mathrm{C}}$ concentration. This causes reduced maximum in the turbidity index (100-\%T) (figure 6A) for $\mathrm{CE}_{2} \mathrm{MAB} . \mathrm{C}_{\mathrm{T}}$ marks the appearance of phase separation (point of maximum solubility of the aggregate) in solution, depending on the types of the constituents to form the complex. As reported earlier, the ethanolic groups have an influence on the local environment of the binding sites in which the altered state of the hydration has a fare share. ${ }^{18}$ They are less susceptible to 
enhance the hydrophilicity of the formed gelatinsurfactant complex, and are more prone to enhance their hydrophobicity due to the substituted ethyl groups. Consequently, all the turbidity related points occur at an early stage for $\mathrm{CE}_{2} \mathrm{MAB}$ in the Group $\mathrm{A}$ series. Similar conclusion can be drawn from the conductance results. $\mathrm{C}_{\mathrm{T}}$ is not visible in the conductance behaviour in the complex formation (figure 7).

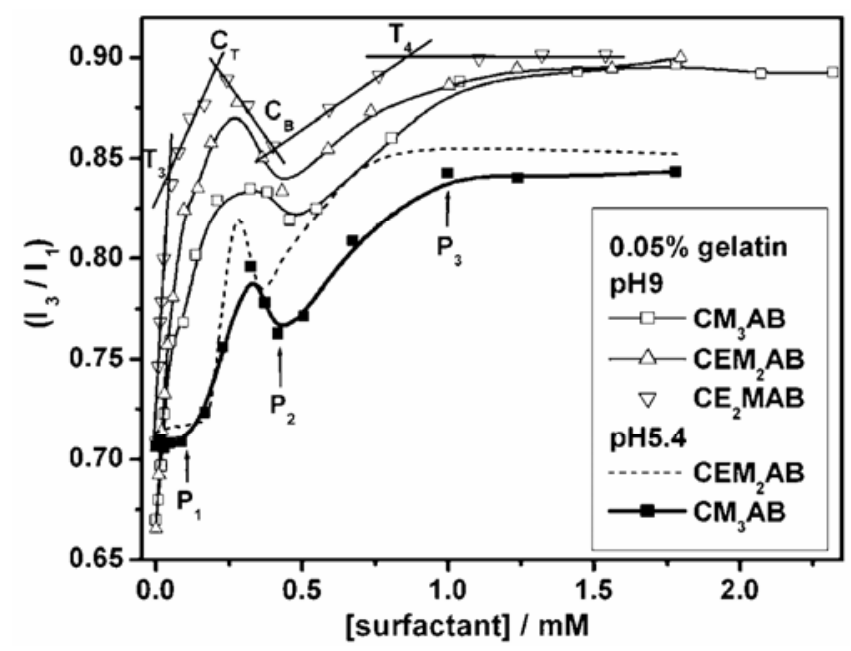

Figure 5. Fluorimetric $\left(\mathrm{I}_{3} / \mathrm{I}_{1}\right)$ dependence of Group $\mathrm{A}$ surfactants in presence of $0.05 \%$ gelatin at $\mathrm{pH} 9.0$ and 5.4, at $303 \mathrm{~K} . \mathrm{CM}_{3} \mathrm{AB}, \mathrm{CEM}_{2} \mathrm{AB}$ and $\mathrm{CE}_{2} \mathrm{MAB}$ at $\mathrm{pH} 9 \cdot 0$ in gelatin. $\mathrm{CEM}_{2} \mathrm{AB}$ and $\mathrm{CM}_{3} \mathrm{AB}$ at $\mathrm{pH} 5.4$ in gelatin. The break points are identified with symbols defined in the text.

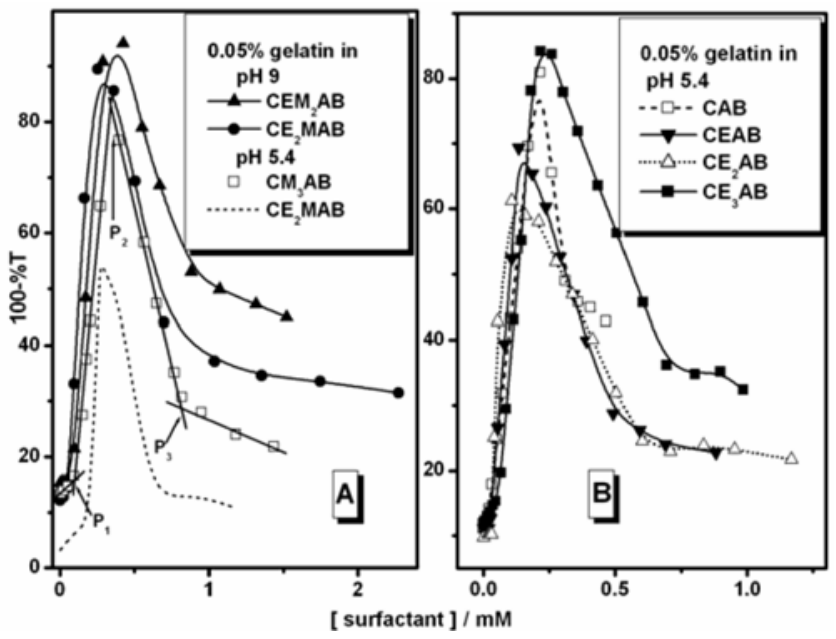

Figure 6. Turbidity profiles of Group A and B surfactants in presence of $0.05 \%$ gelatin at $\mathrm{pH} 9.0$ and 5.4 at $303 \mathrm{~K}$. (A) Profile of $\mathrm{CEM}_{2} \mathrm{AB}$ and $\mathrm{CE}_{2} \mathrm{MAB}$ at $\mathrm{pH} 9 \cdot 0$ and $\mathrm{CM}_{3} \mathrm{AB}$ in pH 5.4. Broken line: profile of $\mathrm{CE}_{2} \mathrm{MAB}$ in $\mathrm{pH} 5.4$ (shown for a comparison). The break points are identified with symbols defined in the text; (B) $\mathrm{CAB}$, $\mathrm{CEAB}, \mathrm{CE}_{2} \mathrm{AB}$ and $\mathrm{CE}_{3} \mathrm{AB}$ at $\mathrm{pH} \mathbf{5 \cdot 4}$.
The charged colloidal polyelectrolyte-type complexes contribute to the conductance of the solution with their dissociated ions. The presence of the ethanolic groups reduces the counterion binding of the surfactant micelles that manifests into a reduced $\beta_{T_{A}}$ with substitution (table 3 ). Lower charge density in the head group lowers the specific conductance of the substituted varieties (figure 8). Calorimetry profile (figure 9) for $\mathrm{CM}_{3} \mathrm{AB}$ forms two peaks (lower

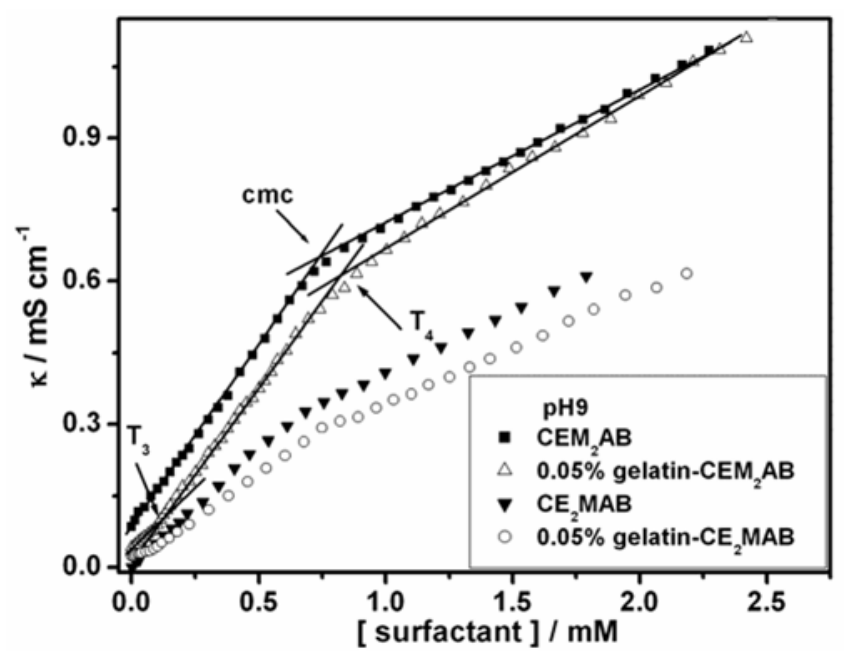

Figure 7. Conductometric profiles of Group A surfacetants at $\mathrm{pH} 9.0$ in $0.05 \%$ gelatin at $303 \mathrm{~K}$. Profiles of $\mathrm{CEM}_{2} \mathrm{AB}$ and $\mathrm{CE}_{2} \mathrm{MAB}$ in buffer without and with gelatin.

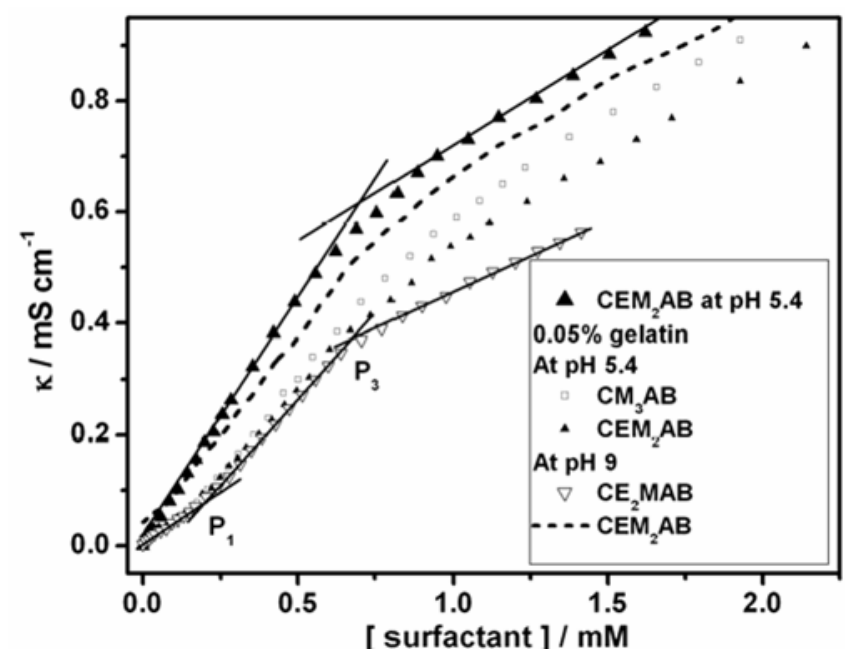

Figure 8. Conductometric interaction profiles of Group $\mathrm{A}$ and B surfactants at $\mathrm{pH} 5.4$ in $0.05 \%$ gelatin at $303 \mathrm{~K}$. Profiles of $\mathrm{CM}_{3} \mathrm{AB}$ at $\mathrm{pH} 9.0$ and $\mathrm{CE}_{2} \mathrm{MAB}$ at $\mathrm{pH} 5.4$ are shown. Profile of $\mathrm{CEM}_{2} \mathrm{AB}$ in buffer at $\mathrm{pH} 5.4$ is illustrated for a comparison of the effects observed at the two $\mathrm{pH}$. 
Table 3. Thermodynamic bulk parameters in the interaction of $0.05 \%$ gelatin with Group A surfactants in $\mathrm{pH} 9.0$ and 5.4 buffer solution at $303 \mathrm{~K}^{\mathrm{a}}{ }^{\mathrm{a}}$

\begin{tabular}{ccccccc}
\hline & & & & \multicolumn{3}{c}{$\Delta H / \mathrm{kJ} \mathrm{mol}^{-1}$} \\
\cline { 5 - 7 } $\mathrm{pH}$ & System & $\beta_{T_{4}}$ & $-\Delta G_{\mathrm{m}}^{\mathrm{o}} / \mathrm{kJ} \mathrm{mol}^{-1}$ & $\Delta H_{1}$ & $\Delta H_{3}$ & $-\Delta H_{4}$ \\
\hline 9.0 & $\mathrm{CM}_{3} \mathrm{AB}$ & 0.62 & $56 \cdot 6$ & 3.33 & 6.66 & 7.74 \\
& $\mathrm{CEM}_{2} \mathrm{AB}$ & 0.57 & $44 \cdot 0$ & 2.90 & 5.83 & 6.44 \\
& $\mathrm{CE}_{2} \mathrm{MAB}$ & 0.44 & 40.9 & $2 \cdot 13$ & 5.12 & 4.85 \\
5.4 & $\mathrm{CM}_{3} \mathrm{AB}$ & 0.51 & 41.9 & 2.08 & 3.56 & 3.14 \\
& $\mathrm{CEM}_{2} \mathrm{AB}$ & 0.52 & 42.7 & 1.50 & 3.74 & 2.37 \\
& $\mathrm{CE}_{2} \mathrm{MAB}$ & 0.57 & 44.7 & 1.33 & $4 \cdot 15$ & 2.54 \\
\hline
\end{tabular}

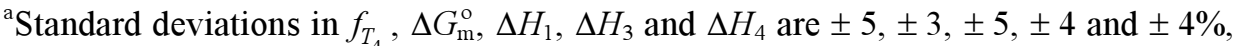
respectively.

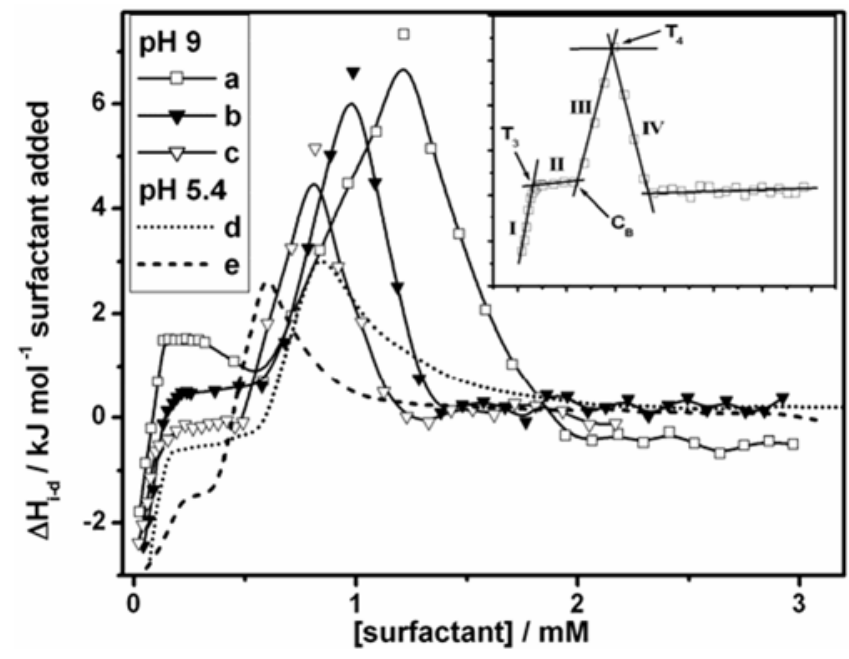

Figure 9. Enthalpograms of Group A surfactants in presence of $0.05 \%$ gelatin at $\mathrm{pH} 9.0$ and 5.4 at $303 \mathrm{~K}$. Main plot: (a) $\mathrm{CM}_{3} \mathrm{AB}$; (b) $\mathrm{CEM}_{2} \mathrm{AB}$; and (c) $\mathrm{CE}_{2} \mathrm{MAB}$ at $\mathrm{pH} 9 \cdot 0$; (d) $\mathrm{CM}_{3} \mathrm{AB}$; and (e) $\mathrm{CE}_{2} \mathrm{MAB}$ at $\mathrm{pH} 5 \cdot 4$. Inset: Representative sections of the thermograms at $\mathrm{pH} 9 \cdot 0$.

and higher). The lower peak flattens with the ethanolic substitution to form a broad plateau (Inset, figure 9), the two ends correspond to $T_{3}$ and $C_{B}$, respectively. The peak heights are prominent at $\mathrm{pH}$ $9 \cdot 0$. The four distinct regions observed in the enthalpogram (Inset, figure 9) with their enthalpies are (I) the gelatin-small micelle complex formation $\left(\Delta H_{1}\right)$; (II) the preliminary association of the complex $\left(\Delta H_{2}\right.$ minor); (III) the advanced aggregation of the complex to form the coacervates $\left(\Delta H_{3}\right)$, and (IV) the formation of bigger micelles in solution $\left(\Delta H_{4}\right)$. The processes I, III and IV are endothermic, endothermic and exothermic, respectively (table 3 ). At $\mathrm{pH} 9.0$, the enthalpy change follows the order $\mathrm{CM}_{3} \mathrm{AB}>$ $\mathrm{CEM}_{2} \mathrm{AB}>\mathrm{CE}_{2} \mathrm{MAB}$. The order of the $\Gamma_{\max }^{\mathrm{T}_{4}}$ and
$A_{\min }$ of the Group A surfactants at $\mathrm{pH} 9 \cdot 0$ and $5 \cdot 4$ without gelatin (table 1) is reverse than their order with gelatin (table 4). The magnitudes of the interfacial parameters in the presence of gelatin are much different from that in the absence. The complex $\mathrm{GS}_{\mathrm{n}}^{1}$ at the interface plays a distinct role in this matter.

3.5b Group A at pH 5.4: Micellar aggregation on the gelatin chain to produce $\mathrm{GS}_{\mathrm{m}}^{\mathrm{B}}$ arises at a later stage at the lower $\mathrm{pH} 5.4$ with less surface activity at each stage for the Group B surfactants (Inset, figure 4 and discussed subsequently). It is observed in the figure 4 (main plot) that the size of the plateau between $\mathrm{P}_{1}$ and $\mathrm{P}_{2}$ diminishes with the ethanolic substitution in the amphiphile head group of Group A surfactants. The plateau constitutes the adjustments among the processes $\mathrm{B}, \mathrm{C}$ and $\mathrm{D}$ to maintain a constant surface pressure. The size decrease is due to reduction in the degree of interaction with substitution. Reduced coacervation thereby diminishes the process $\mathrm{D}$. Thus, the formation of the two hump observed in the tensiometric profile at $\mathrm{pH} 9.0$ (figure 3 ) is absent at $\mathrm{pH} 5 \cdot 4$. The surface excess $\left(\Gamma_{\max }^{\mathrm{T}_{4}}\right)$ drops both for $\mathrm{CEM}_{2} \mathrm{AB}$ and $\mathrm{CE}_{2} \mathrm{MAB}$, with a concomitant increase in the $A_{\min }$ compared with $\mathrm{CM}_{3} \mathrm{AB}$ (table 4). At higher $\mathrm{pH}$, gelatin is a stronger polyelectrolyte and the complexed biopolymer is interacted with more induced micelles and moderately resides at the interface than in the bulk. At pH 5.4, the macromolecule is sparingly complexed, its residence is favorably at the interface. As opposite to $\mathrm{pH} \mathrm{9.0,} \mathrm{the} \mathrm{surface} \mathrm{charge} \mathrm{density} \mathrm{of} \mathrm{the} \mathrm{gelatin-}$ surfactant complex at any stage increases with the ethanolic substitution at $\mathrm{pH} 5 \cdot 4$, registering increase in $\beta_{T_{4}}$ (table 3). The interaction process decreases the conductance of free surfactant ions in the 
Table 4. Interfacial adsorption parameters for the interaction of gelatin with Group A and B surfactants at $\mathrm{pH} 9 \cdot 0$ and $5 \cdot 4 .^{\mathrm{a}}$

\begin{tabular}{|c|c|c|c|c|c|}
\hline $\mathrm{pH}$ & System & $\gamma_{T_{4}} / \mathrm{mN} \mathrm{m}^{-1}$ & $10^{7} \tilde{A}_{\max }^{\mathrm{T}_{4}} / \mathrm{mol} \mathrm{m}^{-2}$ & $A_{\mathrm{min}} / \mathrm{nm}^{2}$ molecule $^{-1}$ & $-\Delta G_{\mathrm{ads}}^{\mathrm{o}} / \mathrm{kJ} \mathrm{mol}^{-1}$ \\
\hline \multirow[t]{3}{*}{$9 \cdot 0$} & $\mathrm{CM}_{3} \mathrm{AB}$ & $34 \cdot 2$ & $5 \cdot 52$ & $3 \cdot 01$ & $87 \cdot 4$ \\
\hline & $\mathrm{CEM}_{2} \mathrm{AB}$ & 33.7 & 6.55 & $2 \cdot 53$ & $101 \cdot 1$ \\
\hline & $\mathrm{CE}_{2} \mathrm{MAB}$ & $33 \cdot 2$ & $6 \cdot 79$ & $2 \cdot 44$ & $96 \cdot 7$ \\
\hline \multirow[t]{7}{*}{$5 \cdot 4$} & $\mathrm{CM}_{3} \mathrm{AB}$ & $34 \cdot 6$ & $6 \cdot 15$ & $2 \cdot 70$ & $101 \cdot 2$ \\
\hline & $\mathrm{CEM}_{2} \mathrm{AB}$ & 34.8 & $4 \cdot 40$ & $3 \cdot 77$ & $125 \cdot 1$ \\
\hline & $\mathrm{CE}_{2} \mathrm{MAB}$ & $35 \cdot 1$ & $2 \cdot 93$ & $5 \cdot 67$ & $167 \cdot 6$ \\
\hline & CAB & $25 \cdot 9$ & $20 \cdot 6$ & $0 \cdot 80$ & $52 \cdot 1$ \\
\hline & CEAB & $24 \cdot 7$ & $15 \cdot 9$ & 1.04 & $58 \cdot 0$ \\
\hline & $\mathrm{CE}_{2} \mathrm{AB}$ & $25 \cdot 0$ & $11 \cdot 7$ & $1 \cdot 42$ & $75 \cdot 0$ \\
\hline & $\mathrm{CE}_{3} \mathrm{AB}$ & $26 \cdot 1$ & $11 \cdot 1$ & 1.49 & $75 \cdot 5$ \\
\hline
\end{tabular}

${ }^{\mathrm{a}}$ Standard deviations in $\gamma_{T_{4}}, \tilde{A}_{\max }^{\mathrm{T}_{4}}, \mathrm{~A}_{\min }$ and $\Delta G_{\text {ads }}^{\mathrm{o}}$ are $\pm 3, \pm 5, \pm 8$ and $\pm 5 \%$, respectively.

presence of gelatin (figure 8). The head group orientation with $\mathrm{pH}$ has a significant say on the surface charge density of the complexes. In the microcalorimetric enthalpogram, the peak heights are significantly lower at $\mathrm{pH} 5.4$, with a decreased enthalpy in all the cases (figure 9 and table 3). The enthalpy of the coacervation $\left(\mathrm{\Delta H}_{3}\right)$ follows a reverse trend of $\mathrm{CE}_{2} \mathrm{MAB}>\mathrm{CEM}_{2} \mathrm{AB}>\mathrm{CM}_{3} \mathrm{AB}$ at $\mathrm{pH} 5.4$ than that at $\mathrm{pH} 9 \cdot 0$. An explanation for the observed trends of $\Delta \mathrm{H}_{3}$ is difficult since various processes may participate in the process. ${ }^{74,75}$ Reduced coacervation leads to a decrease in the maximum turbidity index at the lower $\mathrm{pH}$ to nearly half of that at the higher $\mathrm{pH}$ (figure $6 \mathrm{~A}, \mathrm{CE}_{2} \mathrm{MAB}$ taken as a case). Fluorimetric profile results an initial plateau at the start (figure 5) with a subsequent increase from $P_{1}$. Such a profile is also found in literature. ${ }^{76}$ There is an initial steep rise for the Group A surfactants at $\mathrm{pH} 9.0$ essentially due to the formation of the hydrophobic $\mathrm{GS}_{\mathrm{n}}^{1}$ complex. At $\mathrm{pH} 5 \cdot 4$, the initial surfactant addition causes negligible enhancement in the polarity index or the hydrophobicity as the interaction is reduced significantly at the lower $\mathrm{pH}$ to yield a low concentration of the said complex $\left(\mathrm{GS}_{\mathrm{n}}^{1}\right)$.

3.5c Group B at pH 5.4: Only the tensiometric results are presented for pure Group B surfactants at $\mathrm{pH} 6.5$ and 5.4; at $\mathrm{pH} 9.0$, the compound tends to become poorly soluble. The results discussed are with reference to $\mathrm{pH} 5 \cdot 4$. The CAB and CEAB follow similar profiles (not illustrated) of interfacial and bulk behaviours as discussed in the previous section. The $\mathrm{CE}_{2} \mathrm{AB}$ and $\mathrm{CE}_{3} \mathrm{AB}$ (Inset, figure 4), on the other hand, produce features similar to that of DTAB and TTAB reported earlier. ${ }^{49}$ The characteristic feature of the broad plateau were also found in other systems like SDS/poly(vinylpyridinium chloride) $/ \mathrm{NaCl}(0 \cdot 1 \mathrm{M})$ system, ${ }^{77}$ sodium tetradecylsulfate/polydimethyldiallylammonium chloride $/ 0 \cdot 1 \mathrm{M}$ $\mathrm{NaCl}^{78}$ and the $7 \mathrm{wt} \%$ gelatin-SDS system. ${ }^{79}$ Likewise, for $\mathrm{CE}_{2} \mathrm{AB}$ and $\mathrm{CE}_{3} \mathrm{AB}$, the plateaus appear from the point beyond their aqueous cmcs. Substantial precipitation from the starting point for the $\mathrm{CE}_{3} \mathrm{AB}$ affects the tensiometric measurements. Turbidimetric maximum decreases with increased substitution (figure 6B). This is also true for the Group A surfactants. The $\mathrm{CE}_{3} \mathrm{AB}$ behaves quite odd in this respect. Unlike others, precipitation of its gelatinsurfactant complex does not dissolve at the end. Other methods fail to register the interaction features of the Group B surfactants: this restricts confirmation of the information on the transition points (table 2b). Thus only the cac points can be compared which suggests an order of $\mathrm{CAB}<\mathrm{CEAB}<$ $\mathrm{CE}_{2} \mathrm{AB}<\mathrm{CE}_{3} \mathrm{AB}$ by both tensiometry and turbidimetry. Of course, the extended cmc points obtained from the turbidimetry also follows the order as cac between $\mathrm{CAB}$ and $\mathrm{CEAB}$ found from the tensiometry corroborates with the turbidimetry. In the post interaction stage with gelatin, the $\Gamma_{\max }^{T_{4}}, A_{\min }$ and $\Delta \mathrm{G}_{\text {ads }}^{\mathrm{o}}$ parameters of the Group B surfactants at $\mathrm{pH}$ 5.4 follow the orders concomitant with the ethanolic substitution in the head group of the CAB (table 4).

\section{Conclusions}

Substitution of methyl and/or ethanolic groups in the ammonium head moiety of the surfactant hexadecylammonium bromide plays a crucial role in their surface chemical and bulk behavioural patterns in buffer solution in the absence and presence of gela- 
tin. Such head group architectural feature alters the steric behaviour as well as changes in the surface charge density of the amphiphilic head groups with changing $\mathrm{pH}$. The self-aggregation of these amphiphile molecules in solution thus gets affected. The compromising balance between the two effects (steric and surface charge density) thus play a determinant role in the critical micellar concentration $(\mathrm{cmc})$ in solution. Lower $\mathrm{pH}$ favours early formation of cmc. Interaction of the surfactants with gelatin at different $\mathrm{pH}$ is expected to show differences; two pHs 5.4 and 9.0 are considered to cover the basic region from the vicinity of isoelectric state $(\mathrm{pH} 4.8)$ Ethanolic substitution plays an interesting role in the interactional process. It defers cac at both the $\mathrm{pH} 5.4$ and $9 \cdot 0$, enhances hydrophobicity of the proteinsurfactant complex through inter-association between its chains and shows less efficiency in removing turbidity. Changes in $\mathrm{pH}$ responds in a typical manner: lower $\mathrm{pH}$ reduces the total number of binding sites on gelatin, defers cac, and reduces concentration and surface activity of the proteinsurfactant complex at various stages in the interaction profile. This causes less presence of the complex at the interface in the far end of the interaction process. Surface charge density lessens with substitution at $\mathrm{pH} 9.0$, whereas it enhances with substitution at $\mathrm{pH}$ 5.4. The Group B surfactants are less susceptible to respond to various methods of probing the bulk and the interfacial features; thus a generalized comment on their surface chemical behaviour would be less conclusive than Group A compounds.

\section{Acknowledgements}

D M thanks Jadavpur University for laboratory facilities. S P M thanks the Indian National Science Academy, New Delhi, for an Honorary scientist position. We also thank Dr P K Das of Indian Association of Cultivation of Sciences (IACS), Kolkata for preparing the surfactants.

\section{References}

1. Membrane mimetic chemistry 1982 (eds) J H Fendler (New York: Wiley)

2. Basu Ray G, Chakraborty I, Ghosh S, Moulik S P and Palepu R 2005 Langmuir 2110958

3. El Seoud O A 1989 Adv. Colloid Interface Sci. 301

4. Bijma K, Blandamer M J and Engberts J B F N 1998 Langmuir 1479
5. Bonan C, Germani R, Ponti P P, Savelli G, Cerichelli G, Bacaloglu R and Bunton C A 1990 J. Phys. Chem. 945331

6. Mitra D, Chakraborty I, Bhattacharya S C, Moulik S P, Roy S, Das D and Das P K 2006 J. Phys. Chem. B110 11314

7. Das D and Das P K 2003 Langmuir 199114

8. Das D, Roy S, Mitra R N, Dasgupta A and Das P K 2005 Chem. Eur. J. 114881

9. Goddard E D 1993 In Interaction of Surfactants with Polymers and Proteins (eds) E D Goddard and K P Ananthapadmanabhan (Boca Raton. FL: CRC Press) p. 123

10. Hayakawa K and Kwak J C T 1990 In Cationic surfactants physical chemistry (eds) D N Rubingh and $\mathrm{P}$ M Holland (New York: Marcel Dekker)

11. Nagarajan R 1985 Colloids Surf. 131

12. Vila J A, Ripoll D R and Scheraga H A 2007 J. Phys. Chem. B111 6577

13. Ted Lee C, Smith K A and Hatton T A 2005 Biochemistry $\mathbf{4 4} 524$

14. Chandar P, Somasundaran P and Turro N J 1988 Macromolecules 21950

15. Miller A D 1998 Angew. Chem. Int. Ed. Engl. 371768

16. Moghimi S M 2006 Biomaterials 27136

17. Dasgupta A, Das P K, Dias R S, Miguel M G, Lindman B, Jadhav V M, Gnanamani M and Maiti S 2007 J. Phys. Chem. B111 8502

18. Chatterjee A and Moulik S P 2005 Ind. J. Biochem. Biophys. 42205

19. Rose P I G 1977 In The Theory of the photographic process (eds) T H James (New York: Macmillan) 4th edn, p. 51

20. Howe A M 2000 Curr. Opin. Colloid Interface Sci. 5 288

21. Miller D D, Lenhart W, Antalek B J, Williams A J and Hewitt J M 1994 Langmuir 1068

22. Cooke D J, Dong C C, Thomas R K, Howe A M, Simister E A and Penfold J 2000 Langmuir 166546

23. Cosgrove T, White S J, Zarbakhsh A, Heenan R K and Howe A M 1995 Langmuir 11744

24. Griffiths P C, Cheung A Y F, Jenkins R L, Howe A M, Pitt A R, Heenan R K and King S M 2004 Langmuir 201161

25. Griffiths $\mathrm{P}$ C, Stilbs $\mathrm{P}$, Howe A M and Cosgrove T 1996 Langmuir 122884

26. Griffiths P C, Stilbs P, Howe A M and Whitesides T H 1996 Langmuir 125302

27. Griffiths $\mathrm{P}$ C, Fallis I A, Teerapornchaisit P and Grillo I 2001 Langmuir 172594

28. Griffiths P C, Howe A M, Bales B L, Goyffon P and Rowlands C C 1997 J. Chem. Soc. Perkin Trans. 212 2473.

29. Wustneck R and Miller H-J 1986 Colloid Polym. Sci. 26497

30. Pankhurst K G A and Smith R C M 1944 Trans. Faraday Soc. 40465

31. Cosgrove T, Hone J H E, Howe A M and Heenan R K 1998 Langmuir 145376

32. Wustneck R, Hernel H and Kretzschmar G $1983 \mathrm{~J}$. Colloid Interface Sci. $\mathbf{9 3} 419$ 
33. Buron C, Filiatre C, Membrey F, Foissy A and Argillier J F 2004 Colloid Polym. Sci. 282446

34. Wustneck R and Warnheim T 1988 Colloid Polym. Sci. 266926

35. Whitesides T H and Miller D D 1994 Langmuir 10 2899

36. Knox W J and Wright J F 1965 J. Colloid Interface Sci. 20177

37. Muller D, Malmsten M, Bergenstahl B, Hessing J, Olijve J and Mori F 1998 Langmuir 143107

38. Nikas Y J and Blankschtein D 1994 Langmuir 10 3512

39. Fruhner H and Kretzschmar G 1992 Colloid Polym. Sci. 270177

40. Fruhner H and Kretzchmar G 1989 Colloid Polym. Sci. 267 839; Fruhner H and Kretzchmar G 1992 Colloid Polym. Sci. 270 177; Wustneck R, Hermel H and Kretzschmar G 1984 Colloid Polym. Sci. 262827

41. Bowman W A, Rubinstein M and Tan J S 1997 Macromolecules 303262

42. Griffiths P C, Roe J A, Jenkins R L, Reeve J, Cheung A Y F, Hall D G, Pitt A R and Howe A M 2000 Langmuir 169983

43. Wustneck R, Buder E, Wetzel R and Hermel H 1989 Colloid Polym. Sci. 267516

44. Chatterjee A, Moulik S P, Majhi P R and Sanyal S K 2002 Biophys. Chem. 98313

45. Maulik S, Dutta P, Chattoraj D K and Moulik S P 1998 Colloid Surf. B11 1

46. Rao A, Kim Y, Kausch C M and Thomas R R 2006 Langmuir 227964

47. Wustneck R, Buder E, Wetzel R and Hermel H 1989 Colloid Polym. Sci. 267429

48. Saxena A, Antony T and Bohidar H B 1998 J. Phys. Chem. B102 5063

49. Mitra D, Bhattacharya S C and Moulik S P $2008 \mathrm{~J}$. Phys. Chem. B112 6609

50. Mitra D, Bhattacharya S C and Moulik S P 2009 Biophys. Chem. 139123

51. Chatterjee A, Maiti S, Sanyal S K and Moulik S P 2002 Langmuir 182998

52. Harkins W D and Jordan H F $1930 \mathrm{~J}$. Am. Chem. Soc. 521751

53. Chakraborty T, Chakraborty I and Ghosh S 2006 Langmuir 229905

54. Chakraborty T, Chakraborty I, Moulik S P and Ghosh S 2007 J. Phys. Chem. B111 2736
55. Prasad M, Moulik S P, MacDonald A and Palepu R 2004 J. Phys. Chem. B108 355

56. Shimizu S, Pires P A R and El Seoud O A 2004 Langmuir 209551

57. Lah J, Pohar C and Vesnaver G $2000 \mathrm{~J}$. Phys. Chem. B104 2522

58. Kresheck G C 1998 J. Am. Chem. Soc. 12010964

59. Ropers M H, Czichocki G and Brezesinski G $2003 \mathrm{~J}$. Phys. Chem. B107 5281

60. Konop A J and Colby R H 1999 Langmuir 1558

61. Chakraborty I and Moulik S P 2007 J. Phys. Chem. B 1113658

62. Hait S K, Moulik S P and Palepu R 2002 Langmuir 182471

63. Mitra D, Chakraborty I, Bhattacharya S C and Moulik S P 2007 Langmuir 233049

64. Evans H C 1956 J. Chem. Soc. 579

65. Moulik S P, Haque M E, Jana P K and Das A R 1996 J. Phys. Chem. 100701

66. Matsuoka K, Moroi Y and Saito M 1993 J. Phys. Chem. 9713006

67. Maiti K, Chakraborty I, Bhattacharya S C B, Panda A $\mathrm{K}$ and and Moulik S P 2007 J Phys. Chem. B11 14175

68. Bohidar H B and Jena S S J. Chem. Phys. 1006888

69. Pezron I, Djabourov M and Leblond J. Polymer 32 3201

70. Title of the document Gelatin in Wikipedia, The free Encyclopaedia. Available via http: //en.wikipedia. org/wiki/gelatin. Accessed on 12 June 2009

71. Jones M N 1967 J. Colloid Interface Sci. 2336

72. Noskov B A, Loglio G and Miller R 2004 J. Phys. Chem. B108 18615

73. Turro N J, Lei X-G, Ananthapadmanabhan K P and Aronson M 1995 Langmuir 112525

74. Naghibi H, Tamura A and Sturtevant J M 1995 Proc. Natl. Acad. Sci. (USA) 925597

75. Liu Y, Sturtevant J M 1995 Protein Sci. 42559

76. Honda C, Kamizono H, Matsumoto $\mathrm{K}$ and Endo $\mathrm{K}$ 2004 J. Colloid Interface Sci. 278310

77. Taylor D J F, Thomas R K, Hines J D, Humphreys K and Penfold J 2002 Langmuir 189783

78. Penfold J, Tucker I, Thomas R K, Taylor D J F, Zhang X L, Bell C, Breward C and Howell P 2007 Langmuir 233128

79. Rao A, Kim J and Thomas R K 2005 Langmuir 21 617 